\title{
Company Performance in Nigerian Listed Companies: Do Large Shareholders Expropriate Minority Shareholders?
}

\author{
Robert W. Odewale \\ School of Accountancy, College of Business \\ Universiti Utara Malaysia, 06010, Sintok, Kedah, Malaysia; rowodewale@yahoo.com \\ Hasnah Kamardin \\ School of Accountancy, College of Business \\ Universiti Utara Malaysia, 06010, Sintok, Kedah, Malaysia; hasnahk@uum.edu.my
}

Doi:10.5901/mjss.2015.v6n6p236

\section{Abstract}

It is argued that large shareholders have enormous influence over their companies as their ability to monitor the executives can mitigate the agency problems. This paper examines how large shareholders are related to company performance after distinguishing domestic large shareholders from the foreign large shareholders. Using a panel of 58 companies listed on the Nigerian Stock Exchange with 222 company-year observations from 2009 to 2012, firm-level fixed effects regression was used for analysis. We find evidence that domestic large shareholders are associated with better company performance while foreign large shareholders show a concave relationship with company performance with inflection point at 31.88\%. The empirical result also shows that the joint presence of the both domestic large shareholders and foreign large shareholders in companies seems to make them pursue overall wealth maximization objective of the company. The result is consistent with the contention that concentrated ownership remains an effective corporate governance mechanism in an environment with weak investor protection rights. The study contributes to the corporate governance literature of the substitution effect of large shareholders for effective corporate governance practice.

Keywords: Large Shareholders, Corporate Governance, Company Performance, Nigeria

\section{Introduction}

The corporate scandals and the subsequent financial restatements by companies have once again brought to the fore the effectiveness of the internal corporate governance mechanisms operational in companies. The extant literature documents that poor company performance has been associated with poor corporate governance practice (Chen, Firth, Gao, \& Rui, 2006; Johnson, Boone, Breach, \& Friedman, 2000). Company performance is one of the indices used by investors to evaluate the prospect of companies to enable them make investment decisions. Poor company performance has led to conflicts between investors and managers of companies and to an extent has also led to CEO turnover. There is empirical evidence that companies change their CEOs after reporting poor performance (Hermalin \& Weisbach, 2003). Therefore a good corporate governance mechanism is expected to mitigate the agency conflicts and improve company performance. Several remedies have been suggested as a means of improving corporate governance practice by adequate monitoring of the management at ensuring that they deliver value to the shareholders. One of such is the ownership structure of the company (Shleifer \& Vishny, 1997).

For example, Shleifer and Vishny (1997) contend theoretically that in countries with weak investor protection rights concentrated ownership remains an efficient corporate governance mechanism. Similarly, Cheng and Firth (2005) identified institutional shareholders as good monitors of executive management in companies that prevent managers from exhibiting opportunistic behaviour. An implication of the above submissions is that the presence of large shareholders will lead to improved company performance resulting from effective monitoring. This contention is yet to be empirically examined with recent data from an emerging economy like Nigeria where investor protection right is low coupled with weak enforcement institutions. Nigeria presents an opportunity to investigate how large shareholdings affect company performance because of the high concentration of ownership in a few hands (Sanda, Garba, \& Mikailu, 2011) ranging from institutional, foreign to individual investors unlike the widely diffused ownership structure that characterises US and UK that is predominant in the literature. In addition, there is anecdotal evidence that large shareholders sometimes have 
their representatives on boards of companies in Nigeria. Such presence is expected to serve the interest of their principal.

Extensive research suggests that large shareholders have important role to play in improving company performance ((Boubakri et al., 2005; Chhaochharia, Kumar, \& Niessen-Ruenzi, 2012; Cronqvist \& Fahlenbrach, 2009; Sanda, Mikailu, \& Garba, 2005; Shleifer \& Vishny, 1997). Therefore, the quest by researchers to gain greater insight into how large shareholders influence company performance through their efforts at monitoring management is not recent. The bulk of these studies have used agency theory as the underpinning theory, where there is conflict of interests between the managers and the shareholders (Jensen \& Meckling, 1976). Although there are numerous studies on concentrated ownership and company performance, the results produce substantial variation. The extant literature is equivocal on the behaviour of large shareholders in improving company performance as some of them have been argued to be interested in expropriating the minority shareholders where they are pressure sensitive. On the other hand there are reports of large shareholders being good monitors of managerial actions that lead to improved company performance. For example, prior studies provide evidence of insignificant relationship between large ownership and company performance in addition to evidence that large shareholders expropriate minority shareholders (Chang, 2003; David, Kochhar, \& Levitas, 1998; La Porta, López de Silanes, Shleifer, \& Vishny, 1998; Lemmon \& Lins, 2003). In contrast, there are other research efforts that have reported that the presence of large shareholders lead to improve company performance and prevent managers from extracting private benefits (Boubakri, Cosset, \& Guedhami, 2005; Cheng \& Firth, 2005; Chhaochharia et al., 2012; Cronqvist \& Fahlenbrach, 2009; Mitton, 2002). The issue of whether large shareholders will protect or expropriate the minority shareholders depends on where their interests lie.

La Porta et al. (1998) contend that in many emerging economies there will be increased agency conflicts between controlling shareholders and minority shareholders because of the weak investors' protection rights and almost nonexistent market for corporate control. Consistent with La Porta et al. (1998) argument, Boubakri et al. (2005) argue that many emerging economies do not have good corporate governance system as a result of their inability to put an efficient institutional framework in place. In addition, large shareholders have been identified as another source of agency conflicts in companies because of the inherent tendency in them to expropriate the minority shareholders (La Porta, Lopez-deSilanes, \& Shleifer, 1999).

Our objective in this study is to examine whether large shareholders can improve the performance of companies in an environment with weak institutional corporate governance framework as suggested by Shleifer and Vishny (1997). In support of Shleifer and Vishny's (1997) argument, Boubakri et al. (2005) provide evidence that in countries with weak investor protection rights concentrated ownership remains an effective corporate governance mechanism for improving company performance. Chang (2003) suggests the examination of the type of agency conflicts that exists in companies that have both controlling large shareholders and minority shareholders. We study whether large shareholders are useful in resolving the agency conflict that exists between managers and shareholders in companies or they expropriate minority shareholders by extracting private benefits of control (Holderness, 2003; Shleifer \& Vishny, 1997).

Examining the relationship between large share ownership and company performance the corporate governance literature has distinguished between various types of large shareholders and their investment objective needs. Previous studies have identified large shareholders in some countries to include the state, family and business groups (Chang, 2003; Kato, Kim, \& Lee, 2007; La Porta et al., 1999), but none has identified the role of foreign large shareholders on company performance in an emerging economy like Nigeria with weak investor protection rights. For example, in a recent study Colpan and Yoshikawa (2012) argued that large shareholders have incentive to improve company corporate governance practice even though they do this from different investment objective perspectives. They classified the investor groups as foreign investors and domestic institutional investors.

Shleifer and Vishny (1997) submit theoretically that large shareholders have the incentive not only to recoup their investment but also power to ask for it, and that this invariably leads to improved company performance. In support of this submission we find a statistically significant positive relationship between domestic large shareholders and return on assets, our proxy for company performance. The result is consistent with the findings of Chhaochharia et al. (2012) where they reported significant positive relationship between high domestic share ownership and company performance. We also find an inverted $U$ relationship between foreign large shareholders and company performance with the inflection point at $31.88 \%$. The remainder of this paper is organised as follows. Section 2 discusses literature review and development of hypotheses. Section 3 describes the empirical methodology, data and sample. The main findings are presented in section 4, while section 5 concludes the paper.

\section{Literature Review and Hypotheses Development}

The agency theory discusses the conflict that exists between managers and shareholders because of their different 
preferences (Fama \& Jensen, 1983; Jensen \& Meckling, 1976). This conflict if left unchecked will impact negatively on company performance. Under the agency theory postulation, the manager is seen as self-serving who will act to the detriment of the shareholders to satisfy his own interest if the prevailing environment accommodates it. In order to ensure that the manager does not exhibit any opportunistic behaviour, it is therefore imperative there should be a monitoring mechanism that will serve as check on managerial actions. It was Shleifer and Vishny (1986) in their seminal paper that model the role of large shareholders as a possible variable for mitigating the agency problems that characterise large companies where there is separation of ownership and control. They argued that large shareholders will do adequate monitoring of management that will lead to enhanced company value. In another paper, Shleifer and Vishny (1997) advocated for large share ownership as an integral part of good corporate governance practice. This they argued will make the managers work towards distributing profits to shareholders. They however did not consider that the heterogeneous nature of large shareholders will influence their investment objectives. Empirical support for Shleifer and Vishny (1997) was provided by Becker, Cronqvist, and Fahlenbrach (2011) as they found that large shareholders have enormous influence over their companies and their ability to monitor the executives can mitigate the agency problems.

Large shareholders such as foreign investors and institutional investors have been classified as diverse and shown to have different investment objectives that may not make them present a common front against managers' opportunistic behaviour. The large shareholders could either use their presence to protect the minority shareholders from expropriation or redistribute company resources to themselves (Shleifer \& Vishny, 1997; Mitton, 2002). Their presence will benefit the minority shareholders when they monitor the managers at ensuring that they work to enhance company value. On the other hand when they align with managerial interests they jointly with managers expropriate the minority shareholders.

\subsection{Large shareholders and company performance}

The relationship between large shareholders and company performance has remained a resonating topic in the corporate governance and finance literature. Agency theory has been used by pervious researchers to study large share ownership as a corporate governance mechanism that substitutes board monitoring in a weak corporate governance environment. Previous literature examined the monitoring role of large shareholders in listed companies. One strand of literature examined its relationship with executive compensation but does not provide evidence of its influence on company performance (Cheng \& Firth, 2005; Firth, Fung, \& Rui, 2007; Khan, Dharwadkar, \& Brandes, 2005). Another strand of literature examined its relationship with company performance (Boubakri et al., 2005; Chhaochharia et al., 2012; Cronqvist \& Fahlenbrach, 2009). Chang (2003) argue that positive relationship between large share ownership and company performance can only hold in countries with efficient capital markets and good corporate governance system. The various measures used for company performance produced inconsistent results. Using Tobin's $Q$ as a measure of company performance, Cronqvist and Fahlenbrach (2009) report a positive relationship between large share ownership and company performance. With the use of three different measures of company performance, Boubakri et al. (2005) show a significant positive relationship between large share ownership and company performance after privatization in their multi country study spanning the period 1980 to 2001. The findings of Ozkan (2007) support the conjecture that institutional shareholders do adequate monitoring of management as they report institutional shareholders monitoring of CEO cash compensation in UK. Chhaochharia et al. (2012) find companies with high domestic share ownership to be associated with better financial performance as they engage in effective monitoring of management activities.

In contrast to be above findings, Lemmon and Lins (2003) used 800 companies from 8 countries in East Asia to examine the influence of ownership structure on company performance during financial crisis. They find evidence that large shareholders have incentives to expropriate minority shareholders. In another study, Chang (2003) documents that ownership structure does not have influence on company performance of group-affiliated companies in Korea. Krivogorsky (2006) in her study does not find evidence to support the assertion that the change in percentage shareholdings by institutional large shareholders affects the relationship between institutional ownership and company performance in a nonmonotonic way.

\subsection{Heterogeneous nature of large shareholders}

The heterogeneous nature of large shareholders has made their investment objectives to be divergent. Their investment objectives whether short or long term has also been shown to affect their monitoring behaviour as short term large shareholders are not disposed to intensive monitoring like their long term counterparts will do (Kim, 2010). Institutional investors that make long term investments in companies will be active in monitoring management so as to improve company performance (Ozkan, 2007). Derrien, Kecskés, and Thesmar (2013) report investor horizons affect corporate 
behaviour as long-term investors behave differently from short-term investors. The presence of foreign shareholders is argued will enhance the quality of corporate governance in companies that in turn translates to improved company performance (Dyck \& Zingales, 2004).

Furthermore, David et al. (1998) provides evidence that large shareholders that are pressure sensitive are inclined to align with the interest of management instead of the shareholders. They also show that such large shareholders expropriate the minority shareholders. This is consistent with the findings of Mitton (2002) in their multi country study of the impact of corporate governance on the East Asian financial crisis. It is thus evident that certain large shareholder groups may be indifferent to monitoring management and this will invariably affect company performance as such managers remain unchecked. Significant positive relationship of large shareholders with company performance remains an indication of convergence of interest with minority shareholders while an insignificant relationship indicates expropriation of minority shareholders.

We derive our study hypotheses from the foregoing arguments and state them as follows.

H1: The presence of domestic large shareholders in Nigerian Listed Companies will have significant positive effect on company performance.

$\mathrm{H} 2$ : The presence of foreign large shareholders in Nigerian Listed Companies will have significant positive effect on company performance.

\section{Empirical Methodology, Data and Variables}

\subsection{Empirical Methodology}

We examine the relationship between company performance and large shareholders. Panel data methodology is used for analysis. Panel data methodology allows for the control of unobservable company characteristics and also helps ease the problem of correlated omitted variables (Conyon \& He, 2011; Graham, Li, \& Qiu, 2012; Wooldridge, 2002). When there are correlated omitted effects, panel data helps to get consistent estimates of the parameters of interest which is not ordinarily possible with OLS on individuals' cross sections (Johnston \& DiNardo, 1997). Next, we examined the appropriateness of the fixed-effects model by conducting firm-fixed effects test, time-effects test, random effects test, and Hausman's specification test. Firm-fixed effects is found to be needed while time-effects was not supported.

The Hausman's specification test supports the appropriateness of the fixed effect model over the random effects model. The regressions were run after conducting heteroscedasticity and serial correlation tests. We also examined for the possibility of the existence of either concave or convex relationship between large shareholders and company performance by including the squared terms of domestic large shareholders and foreign large shareholders into the model.

\subsection{Sample}

The unit of analysis is the companies listed on the Nigerian Stock Exchange (NSE). The data for this study comprises information obtained from the annual reports of companies listed on the NSE during the period 2009 to 2012. The initial sample consists of 116 companies, after excluding the insurance sector companies it was reduced to 104 companies. Any company whose annual report for a minimum of three years during the study period was not available was excluded from the sample. This was further reduced to 58 companies comprising 222 company-year observations that formed the final sample because of unavailability of data. The relevant information were hand sorted and computed by the researchers.

In examining the relation between company performance and large shareholders the study separates large shareholders into domestic large shareholders and foreign large shareholders similar to classification by Colpan and Yoshikawa (2012). As discussed earlier, large shareholders may be either short term or long term investors that will make their investment objectives to differ. It has also been documented that domestic and foreign shareholders have different investment objectives (Colpan \& Yoshikawa, 2012). It is this divergent investment objective that makes large shareholders to either take delight in monitoring the management or to expropriate the minority shareholders.

We construct our variables for examining the study hypotheses from the data obtained above. These variables include company performance, domestic large shareholders, foreign large shareholders, directors share ownership, CEO share ownership, gender diversity, board size, board composition, company size, leverage, and sales growth. The definitions of these variables are provided hereunder. 


\subsection{Dependent variable}

Company performance (FP) is the dependent variable of study. Different measures such as return on assets (ROA), return on equity (ROE), stock return, and Tobin's $Q$ have been used previously in the literature as proxies for company performance (Anderson \& Bizjak, 2003; Colpan \& Yoshikawa, 2012; Mehran, 1995; Sarkar \& Sarkar, 2009). In this study we use two performance measures. The first measure is ROA and ROE is the second. Both are accounting-based measures of performance that is not influenced by stock market behaviour (Krivogorsky, 2006). ROA is commonly used to measure management's efficiency to manage company's assets while the ROE is used to evaluate managerial effort at delivering returns to the shareholders based on their equity holdings. ROA is measured as the earnings before interests and taxes deflated by total assets (Krivogorsky, 2006; Luo \& Jackson, 2012; Rashid, De Zoysa, Lodh, \& Rudkin, 2010). ROE is measured as the earnings before interests and taxes divided by the book value of equity (Ehikioya, 2009). The market value of shares at year end is not disclosed by several companies as such we are unable to include the stock measure of performance.

\subsection{Independent variables}

Domestic large shareholders (DOLSO) and foreign large shareholders (FOLSO) form the independent variables of study. Previous studies have measured large shareholders as the total shareholdings by shareholders that hold a minimum of $5 \%$ shares in the company (Kim, 2010; Mehran, 1995; Mitton, 2002). To qualify as a substantial shareholder in NLCs the listing requirements of the NSE requires such shareholder to hold a minimum of $5 \%$ shares in the company. Consistent with past studies and listing requirement of the NSE, the minimum $5 \%$ share holdings used in this study include both direct and indirect holdings. The proxy for domestic large shareholders and foreign large shareholders is the proportion of shares they hold to the total number of shares in the company (Munisi, Hermes, \& Randøy, 2014).

\subsection{Control variables}

Other variables that might influence performance are controlled for in the study. These variables include directors' share ownership (DIRSO), CEO share ownership (CEOSO), gender diversity (GEND), board size (BDS), board composition (BDCOM), company size (SIZE), leverage (LEV), and growth (GRT). Bhagat, Carey, and Elson (1999) argue that substantial shareholdings by directors will align their interests with those of the shareholders as this will encourage them to do proper monitoring of the management. Directors' share ownership is measured as the percentage of shares held by the directors (Ehikioya, 2009; Firth, Tam, \& Tang, 1999). Past research have found positive relationship between managerial ownership and company value (Hermalin \& Weisbach, 1988; Mehran, 1995; Morck, Shleifer, \& Vishny, 1988). Florackis, Kostakis, and Ozkan (2009) find a positive statistical relationship between executive share ownership and company performance in large UK companies. These findings align with the position of the agency theory that higher shareholdings by managers will make them work towards the company's wealth maximization objective (Jensen \& Meckling, 1976). Consistent with previous research, CEO share ownership is measured as the proportion of shares held by the CEO to the total shares outstanding (Munisi et al., 2014).

We control for gender diversity using the proportion of female board members to total board members (Farrell \& Hersch, 2005). The gender of the CEO is reported to have effect on company performance (Khan \& Vieito, 2013) just as Singh, Terjesen, and Vinnicombe (2008) provide evidence that women have the requisite human capital for board positions. Prior studies have reported the influence of board size on company performance (Ehikioya, 2009; Yermack, 1996). Large boards are reported to have coordination problem that makes it difficult for them to reach consensus at making important decisions. There is empirical evidence of a negative association between company performance and board size (Rashid et al., 2010). We measure board size as the total number of directors on board (Kamardin \& Haron, 2011). To control for board independence, the study includes a measure for board composition, which is computed as the proportion of non-executive directors to total number of directors (Kamardin \& Haron, 2011; Linck, Netter, \& Yang, 2008; Munisi et al., 2014). Past studies have shown that boards with more outside directors are associated with lower company performance (Koerniadi \& Tourani-Rad, 2012).

The size of the company is an important variable when investigating company performance. The extant literature documents a significant positive relationship between company size and company performance, indicating that larger companies are more profitable than their smaller counterparts (Koerniadi \& Tourani-Rad, 2012). For this study the log of total assets is used to control for company size (Krivogorsky, 2006). High levered companies are more likely to face financial and credit risk that in turn have effect on financial performance. Prior studies have suggested a negative 
relationship exists between debt and performance (Koerniadi \& Tourani-Rad, 2012). Proxy for leverage is the ratio of total liabilities to total assets (Eng \& Mak, 2003; Munisi et al., 2014). Finally, growth is defined as the percentage of sales' growth between the preceding year and the year of interest as used by (Colpan \& Yoshikawa, 2012).

\subsection{Model specification}

The empirical models for the study are as follows:

a. Using linear specification

$$
\begin{aligned}
& F P(R O A)_{i t}=\beta_{o}+\beta_{1} D_{O L S O}+\beta_{2} F \text { LSO }_{i t}+\beta_{3} \text { DIRSO }_{i t}+\beta_{4} \text { CEOSO }_{i t}+\beta_{5} G E N D_{i t}+\beta_{6} \text { BDS }_{i t}+ \\
& \beta_{7} \text { BDCOM }_{i t}+\beta_{8} \text { SIZE }_{i t}+\beta_{9} L E V_{i t}+\beta_{10} G R T_{i t}+\varepsilon_{i t} \quad \ldots . .1
\end{aligned}
$$

b. Using quadratic specification

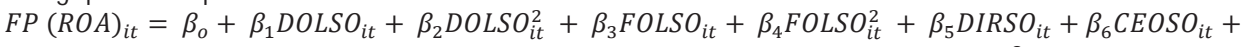
Where:

$$
\beta_{7} G E N D_{i t}+\beta_{8} B D S_{i t}+\beta_{9} B D C O M_{i t}+\beta_{10} S I Z E_{i t}+\beta_{11} L E V_{i t}+\beta_{12} G R T_{i t}+\varepsilon_{i t} \quad \ldots \ldots .2
$$

$\begin{array}{lll}\text { FP } & = & \text { Company performance } \\ \text { DOLSO } & = & \text { Domestic large shareholders } \\ \text { DOLSO }^{2} & = & \text { Domestic large shareholders square } \\ \text { FOLSO } & = & \text { Foreign large shareholders } \\ \text { FOLSO } & = & \text { Foreign large shareholder square } \\ \text { DIRSO } & = & \text { Directors share ownership } \\ \text { CEOSO } & = & \text { CEO share ownership } \\ \text { GEND } & = & \text { Gender diversity } \\ \text { BDS } & = & \text { Board size } \\ \text { BDCOM } & = & \text { Board composition } \\ \text { SIZE } & = & \text { Company size } \\ \text { LEV } & = & \text { Leverage } \\ \text { GRT } & = & \text { Growth } \\ \varepsilon & = & \text { Error term } \\ \text { I } & = & \text { Company } 1 \text { to } n \\ \text { T } & = & \text { Year } 1 \text { to t }\end{array}$

\section{Empirical Results}

\subsection{Descriptive Statistics}

The different variables used for this study as presented in Table 1 shows the study descriptive statistics. We find 84 observations representing $37.83 \%$ of the sample to have the presence on FOLSO while 171 observations representing $77 \%$ of the sample has the presence of DOLSO. We also find that the FOLSO in all the 23 companies in our sample during the period of study retained their substantial shareholdings. This suggests that they hold their investments on longterm basis. Majority of the companies in the sample are under the influence of shareholders with substantial shareholdings. Overall, the sample companies have an average FP of $10.28 \%$ covering a wide range from $-92.69 \%$ minimum to $57.76 \%$ maximum, suggesting wide variation and low profitability rate among the companies. The DOLSO ownership variable has a minimum of $0 \%$, maximum of $94.89 \%$ and average value of $26.96 \%$. This suggests that more than one-quarter of equity holdings in most NLCs are held by DOLSO.

On average, FOLSO constitute $22.69 \%$ of equity holders in NLCs. An implication of this is that there is high ownership concentration in NLCs consistent with the findings of Sanda et al. (2011). The DIRSO variable is on average $15.37 \%$, a minimum of $0 \%$ and maximum of $91.36 \%$. The level of CEOSO is low with average CEO shareholding at $3.34 \%$. The average GEND is 0.85 representing $8.87 \%$ of total board members. The average BDS is 9.5 members while the average BDCOM stood at $68.23 \%$. This indicates high board independence among NLCs. The average LEV is $61.94 \%$ of the equity of sample companies. Finally, GRT is found to average $12.44 \%$ for NLCs during the sample period. 
Table 1. Descriptive Statistics and Variance Inflation Factor $(N=222)$

\begin{tabular}{lccccc}
\hline Variables & Mean & Std. Dev. & Minimum & Maximum & VIF \\
\hline ROA & 0.1028 & 0.1334 & -0.9269 & 0.5776 & - \\
DOLSO & 0.2670 & 0.2605 & 0.0000 & 0.9489 & 2.17 \\
FOLSO & 0.2269 & 0.2896 & 0.0000 & 0.7500 & 1.74 \\
DIRSO & 0.1537 & 0.2255 & 0.0000 & 0.9136 & 1.79 \\
CEOSO & 0.0339 & 0.0886 & 0.0000 & 0.4000 & 1.49 \\
GEND & 0.8468 & 1.0438 & 0.0000 & 5.0000 & 1.58 \\
BDS & 9.5450 & 3.1169 & 5.0000 & 20.0000 & 2.54 \\
BDCOM & 0.6823 & 0.1436 & 0.2000 & 0.9333 & 1.25 \\
SIZE & 17.1848 & 2.2088 & 12.0316 & 21.8821 & 2.47 \\
LEV & 0.6194 & 0.2116 & 0.1161 & 1.3779 & 1.16 \\
GRT & 0.1244 & 0.2093 & -0.5077 & 0.8032 & 1.08 \\
\hline
\end{tabular}

\subsection{Correlation and Multicollinearity Analysis}

The correlation matrix is reported in Table 2. Company performance shows significant correlation with three ownership variables; foreign large shareholders, directors' share ownership, and CEO share ownership. It can be seen that there is a negative correlation between performance and domestic large shareholders even though at an insignificant level.

Domestic large shareholders and directors' ownership show significant correlation with five other independent and control variables. CEO share ownership has a significant negative relationship with performance. While the result of CEO ownership can be interpreted as expropriation by the CEOs, that of the foreign large shareholders is an indication that they will do proper monitoring of management at ensuring that they deliver value to the shareholders.

Significant correlation between variables could be indication that multicollinearity is an issue. The highest correlation is between BDS and SIZE but not more than 0.80. Further, the variance inflation factor (VIF) test was conducted for the independent and control variables. All the variables reported a score less than 3 suggesting that multicollinearity issues are not present in this study.

Table 2. Correlation Matrix

\begin{tabular}{|c|c|c|c|c|c|c|c|c|c|c|c|}
\hline & ROA & DOLSO & FOLSO & DIRSO & CEOSO & GEND & BDS & $\mathrm{BCOM}$ & SIZE & LEV & GRT \\
\hline ROA & 1 & & & & & & & & & & \\
\hline \multirow[t]{2}{*}{ DOLSO } & -0.0800 & 1 & & & & & & & & & \\
\hline & $(0.2349)$ & & & & & & & & & & \\
\hline \multirow[t]{2}{*}{ FOLSO } & $0.1721^{\star \star}$ & $-0.5889 * \star \star$ & 1 & & & & & & & & \\
\hline & $(0.0102)$ & $(0.0000)$ & & & & & & & & & \\
\hline \multirow[t]{2}{*}{ DIRSO } & $-0.2445^{\star \star \star}$ & $0.4089^{\star \star \star}$ & $-0.2244^{\star \star *}$ & 1 & & & & & & & \\
\hline & $(0.0002)$ & 0.0000 & $(0.0008)$ & & & & & & & & \\
\hline \multirow[t]{2}{*}{ CEOSO } & $-0.1385^{\star *}$ & $0.2488^{\star * *}$ & $-0.1671^{\star *}$ & $0.5435^{\star \star \star}$ & 1 & & & & & & \\
\hline & $(0.0393)$ & $(0.0002)$ & $(0.0127)$ & $(0.0000)$ & & & & & & & \\
\hline \multirow[t]{2}{*}{ GEND } & -0.0480 & $-0.2723^{\star \star \star}$ & -0.0129 & $-0.2317^{\star \star \star}$ & $-0.1465^{\star \star}$ & 1 & & & & & \\
\hline & $(0.4771)$ & $(0.0000)$ & $(0.8487)$ & $(0.0005)$ & $(0.0291)$ & & & & & & \\
\hline \multirow[t]{2}{*}{ BDS } & -0.0897 & $-0.3066^{\star \star *}$ & -0.0667 & $-0.2580^{\star * *}$ & $-0.2462^{\star \star *}$ & $0.5626^{\star * *}$ & 1 & & & & \\
\hline & $(0.1829)$ & $(0.0000)$ & $(0.3224)$ & 0.0001 & $(0.0002)$ & $(0.0000)$ & & & & & \\
\hline \multirow[t]{2}{*}{ BCOM } & 0.0624 & $0.2113^{\star \star \star}$ & -0.0651 & $-0.1329 * *$ & -0.1220 & $-0.2289^{\star \star \star}$ & -0.1303 & 1 & & & \\
\hline & $(0.3548)$ & $(0.0015)$ & $(0.3346)$ & $(0.0479)$ & $(0.0696)$ & $(0.0006)$ & $(0.0526)$ & & & & \\
\hline \multirow[t]{2}{*}{ SIZE } & -0.0307 & $-0.3249^{* \star *}$ & 0.0391 & $-0.3194^{\star \star *}$ & $-0.2397^{\star \star *}$ & $0.4681^{\star * *}$ & $0.7085^{\star \star *}$ & $-0.2358^{\star \star \star}$ & 1 & & \\
\hline & $(0.6487)$ & $(0.0000)$ & $(0.5622)$ & $(0.0000)$ & $(0.0003)$ & $(0.0000)$ & $(0.0000)$ & $(0.0004)$ & & & \\
\hline \multirow[t]{2}{*}{ LEV } & $-0.3744^{\star \star \star}$ & -0.0201 & -0.0713 & 0.0093 & -0.0921 & $0.1704^{* *}$ & $0.2282^{\star \star \star}$ & $-0.1271^{*}$ & $0.3335^{\star * *}$ & 1 & \\
\hline & $(0.0000)$ & $(0.7655)$ & $(0.2902)$ & $(0.8899)$ & $(0.1717)$ & $(0.0110)$ & $(0.0006)$ & $(0.0587)$ & $(0.0000)$ & & \\
\hline \multirow[t]{2}{*}{ GRT } & $0.2059^{* \star *}$ & -0.0891 & -0.0178 & 0.0017 & -0.0476 & 0.0248 & 0.1270 & $-0.1412^{\star *}$ & $0.2121^{\star * *}$ & 0.0306 & 1 \\
\hline & $(0.0020)$ & $(0.1857)$ & $(0.7915)$ & $(0.9799)$ & $(0.4801)$ & $(0.6738)$ & $(0.0589)$ & $(0.0354)$ & 0.0015 & 0.6497 & \\
\hline
\end{tabular}

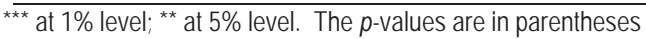


Table 3. Fixed effects regression on the determinants of company performance

\begin{tabular}{|c|c|c|c|c|c|c|}
\hline & 1 & 2 & 3 & 4 & 5 & 6 \\
\hline \multirow[t]{2}{*}{ Constant } & 0.514 & 0.532 & 0.469 & 0.466 & 0.506 & 0.461 \\
\hline & $(1.04)$ & (1.09) & $(0.94)$ & $(0.96)$ & $(1.05)$ & $(0.95)$ \\
\hline \multirow[t]{2}{*}{ DOLSO } & $0.164^{*}$ & $0.166^{*}$ & & -0.133 & -0.064 & \\
\hline & $(1.77)$ & $(1.76)$ & & $(-1.02)$ & $(-0.50)$ & \\
\hline \multirow[t]{2}{*}{ DOLSOsq } & & & & $0.441^{*}$ & $0.412^{*}$ & \\
\hline & & & & $(1.87)$ & $(1.75)$ & \\
\hline \multirow[t]{2}{*}{ FOLSO } & 0.144 & & 0.152 & $0.711^{\star \star \star}$ & & $0.754^{\star \star \star}$ \\
\hline & $(0.91)$ & & $(0.81)$ & $(3.21)$ & & (3.58) \\
\hline \multirow[t]{2}{*}{ FOLSOsq } & & & & $-1.115^{\star \star}$ & & -1.178 \\
\hline & & & & $(-2.36)$ & & $(-2.62)$ \\
\hline \multirow[t]{2}{*}{ DIRSO } & 0.002 & 0.001 & 0.006 & 0.004 & 0.002 & 0.006 \\
\hline & $(0.06)$ & $(0.01)$ & $(0.15)$ & $(0.09)$ & $(0.04)$ & $(0.14)$ \\
\hline \multirow[t]{2}{*}{ CEOSO } & 0.222 & 0.225 & 0.189 & 0.249 & 0.253 & 0.197 \\
\hline & $(0.96)$ & $(0.98)$ & $(0.78)$ & (1.15) & (1.16) & $(0.84)$ \\
\hline \multirow[t]{2}{*}{ GEND } & -0.013 & -0.014 & -0.012 & -0.010 & -0.014 & -0.009 \\
\hline & $(-1.26)$ & $(-1.32)$ & $(-1.11)$ & $(-0.98)$ & $(-1.34)$ & $(-0.85)$ \\
\hline \multirow[t]{2}{*}{ BDS } & -0.001 & -0.002 & -0.001 & -0.002 & -0.002 & -0.002 \\
\hline & $(-0.29)$ & $(-0.37)$ & $(-0.24)$ & $(-0.53)$ & $(-0.42)$ & $(-0.44)$ \\
\hline \multirow[t]{2}{*}{$\mathrm{BCOM}$} & -0.076 & -0.074 & -0.092 & -0.073 & -0.078 & -0.078 \\
\hline & $(-1.33)$ & $(-1.31)$ & $(-1.55)$ & $(-1.34)$ & $(-1.42)$ & $(-1.38)$ \\
\hline \multirow[t]{2}{*}{ SIZE } & -0.006 & -0.005 & 0.000 & -0.000 & -0.003 & 0.002 \\
\hline & $(-0.17)$ & $(-0.14)$ & $(0.00)$ & $(-0.01)$ & $(-0.10)$ & $(0.06)$ \\
\hline \multirow[t]{2}{*}{ LEV } & $-0.543^{\star \star}$ & $-0.543^{\star \star}$ & -0.546 & $-0.544^{\star \star}$ & $-0.529^{\star \star}$ & $-0.560^{\star *}$ \\
\hline & $(-2.18)$ & $(-2.18)$ & $(-2.17)$ & $(-2.20)$ & $(-2.17)$ & $(-2.22)$ \\
\hline \multirow[t]{2}{*}{ GRT } & $0.109^{\star \star *}$ & $0.109^{\star \star *}$ & $0.109^{\star * *}$ & $0.112^{\star * *}$ & $0.109^{\star \star *}$ & $0.111^{\star \star \star}$ \\
\hline & $(2.72)$ & $(2.72)$ & $(2.66)$ & $(2.82)$ & $(2.80)$ & $(2.70)$ \\
\hline$N$ & 222 & 222 & 222 & 222 & 222 & 222 \\
\hline F-stat & $5.12^{\star \star \star}$ & $5.19^{\star \star *}$ & $4.71^{\star * \star}$ & $39.76^{\star \star \star}$ & $4.78^{\star \star \star}$ & $79.27^{\star \star \star}$ \\
\hline Adjusted $\mathrm{R}^{2}$ & 0.3732 & 0.3743 & 0.3693 & 0.3891 & 0.3803 & 0.3814 \\
\hline
\end{tabular}

\subsection{Multivariate Results}

We report regression results of FP on DOLSO and FOLSO after controlling for directors' share ownership, CEO share ownership, gender diversity, board size, board composition, size, leverage, and growth in Table 3. Columns 1 - 3 present the linear specification for firm level fixed effects regression results while Columns 4 - 6 show the quadratic specification for firm level fixed effects regression results. For the linear specification contained in column 1, the regression model is significant at $1 \%$ with F-statistics of 5.12 indicating that the model is appropriately specified. The adjusted $\mathrm{R}^{2}(0.3732)$ shows that the model accounts for more than $37 \%$ of the variations in FP. On the relationship between DOLSO and FP we find a relationship that is positive and statistically significant at $10 \%$ level $(\beta=0.164, t=1.77)$. The result is consistent with that of past research in the field (Chhaochharia et al., 2012; Cronqvist and Fahlenbrach, 2009). It however contrasts the findings of Boubakri et al. (2005) where they reported an insignificant relationship between local institutions' ownership and company performance. This finding supports the prediction of $\mathrm{H} 1$ that the DOLSO will have significant positive effect on FP. This finding is consistent with the view that the presence of block shareholders can help reduce the agency conflicts. This is because they have the incentives to do proper monitoring of the executives to constrain them from self-serving behaviour.

The result shows that the relationship between FP and FOLSO is insignificant. There is no support for H2. This result does not support the position of Dyck and Zingales (2004) that the presence of foreign shareholders will enhance company performance through quality corporate governance practice. This could be an indication that large foreign 
shareholders in NLCs are not interested in the accounting based measure of performance. On the control variables, LEV is negatively related to FP at $5 \%$ level $(\beta=-0.543, t=-2.18)$. GRT shows a significant positive relationship with FP at $1 \%$ level $(\beta=0.109, t=2.72)$. DIRSO, CEOSO, GEND, BDS, BCOM, and SIZE are not significantly related with FP. Our results remain qualitatively similar when we enter DOLSO and FOLSO separately into the models as shown in columns 2 and 3 respectively. This strengthens our findings on the association between FP and large shareholders in the main regression model.

Columns 4 - 6 re-examines the above results by examining the non-linear relationship between FP and large shareholders. As for the DOLSO we find a negative relationship with FP that is not significant $(\beta=-0.133, t=-1.02)$ while the DOLSOsq shows a significant positive relationship with FP at $10 \%$ level $(\beta=0.441, t=1.87)$. This result does not provide evidence of a nonlinear relationship between FP and DOLSO. In contrast, we find a statistically significant positive relationship between FP and FOLSO at $1 \%$ level $(\beta=0.711, t=3.21)$ on the one hand, and a statistically significant negative relationship between FP and FOLSOsq at $5 \%$ level $(\beta=-1.115, t=-2.36)$ on the other. We thus find evidence of an inverted $U$ relationship between FP and FOLSO with the inflection point at $31.88 \%$. This finding implies that there is a certain level up to which the FOLSO will show positive relationship with FP beyond which it will turn negative. This indicates a move from convergence of interest to entrenchment behaviour by FOLSO. The results for LEV and GRT are consistent with those under the linear specification model in column 1. The result does not show any significant relationship between FP and other control variables similar to the linear specification model result. Similar to the linear specification we run separate regressions to examine quadratic relationship for DOLSO and FOLSO in columns 5 and 6 respectively and the result remains consistent with that of column 4 reinforcing the findings of concave relationship between FP and FOLSO.

\subsection{Robustness checks}

To examine the robustness of our findings we substitute ROE for ROA in the regression models. In the linear specification, DOLSO and FOLSO show insignificant relationship with FP. The result is contrary to the finding under ROA where DOLSO is associated with higher company performance but consistent with the finding for FOLSO. For the quadratic specification, there is no evidence of a nonmonotonic relationship between FP and large shareholders (DOLSO and FOLSO). This also contrasts with the ROA result where FOLSO shows a concave relationship with FP.

Additional sensitivity test was conducted by combining DOLSO and FOLSO to form total large shareholders while ROA was used as proxy for FP. We find a significant relationship between FP and total large shareholders at $5 \%$ level ( $\beta$ $=0.159, t=2.05$ ). This is an indication that the joint presence of both DOLSO and FOLSO in companies may make them pursue overall wealth maximization objective of the company. The result of the quadratic specification does not provide any evidence of a non-linear relationship. We do not provide the results of these regressions because of space.

\section{Conclusion}

We have examined whether the presence of large shareholders will help mitigate the agency problem that exists between managers and shareholders in corporate organizations or lead to expropriation of minority shareholders in NLCs. We do this by examining the relationship between large shareholders and company performance after controlling for directors' share ownership, CEO share ownership, gender diversity, board size, board composition, company size, leverage, and sales growth. This study extends previous corporate governance literature by including a new variable identified as foreign large shareholders to distinguish it from domestic large shareholders.

The study has shown that there is divergence of interests among different large shareholders due to their diverse investment objective. We find a positive relationship between FP and DOLSO similar to the finding of Chhaochharia et al. (2012) that companies with high domestic ownership report better performance. We also find a concave relationship exists between FP and FOLSO. The implication is that FOLSO may enhance company performance until they become pressure sensitive that will lead to lower performance. The result also shows that the joint presence of the both DOLSO and FOLSO in companies may ensure higher performance. It is therefore unlikely that large shareholders behave to expropriate minority shareholders in NLCs.

There are certain limitations in the study that should be considered in further studies. The domestic large shareholders are heterogeneous that includes inside large shareholders and outside large shareholders such as institutional investors, individuals and executive management. We have not endeavoured to do any separation in this study due to the low transparency level of ownership disclosure in NLCs. Also, no attempt is made to classify large shareholders into long-term and short-term investors. The limitations of the study notwithstanding, the result supports 
theoretical contentions that large shareholders substitute for effective corporate governance mechanism in countries with weak investor protection rights.

\section{References}

Anderson, R. C., \& Bizjak, J. M. (2003). An empirical examination of the role of the CEO and the compensation committee in structuring executive pay. Journal of Banking \& Finance, 27(7), 1323-1348.

Becker, B., Cronqvist, H., \& Fahlenbrach, R. (2011). Estimating the Effects of Large Shareholders Using a Geographic Instrument. Journal of Financial and Quantitative Analysis, 46(04), 907-942.

Bhagat, S., Carey, D. C., \& Elson, C. M. (1999). Director ownership, corporate performance, and management turnover. The Business Lawyer, 54(3), 885-919.

Boubakri, N., Cosset, J.-C., \& Guedhami, O. (2005). Postprivatization corporate governance: The role of ownership structure and investor protection. Journal of Financial Economics, 76(2), 369-399.

Chang, S. J. (2003). Ownership Structure, Expropriation, and Performance of Group-Affiliated Companies in Korea. Academy of Management Journal, 46(2), 238-253.

Chen, G., Firth, M., Gao, D. N., \& Rui, O. M. (2006). Ownership structure, corporate governance, and fraud: Evidence from China. Journal of Corporate Finance.

Cheng, S., \& Firth, M. (2005). Ownership, Corporate Governance and Top Management Pay in Hong Kong. Corporate Governance, 13(2), 291-302.

Chhaochharia, V., Kumar, A., \& Niessen-Ruenzi, A. (2012). Local investors and corporate governance. Journal of Accounting and Economics, 54(1), 42-67.

Colpan, A. M., \& Yoshikawa, T. (2012). Performance Sensitivity of Executive Pay: The Role of Foreign Investors and Affiliated Directors in Japan. Corporate Governance: An International Review, 20(6), 547-561.

Conyon, M. J., \& He, L. (2011). Executive compensation and corporate governance in China. Journal of Corporate Finance, 17(4), 1158-1175.

Cronqvist, H., \& Fahlenbrach, R. (2009). Large Shareholders and Corporate Policies. The Review of Financial Studies, 22(10), 39413976.

David, P., Kochhar, R., \& Levitas, E. (1998). The effect of institutional investors on the level and mix of CEO compensation. Academy of Management Journal, 41(2), 200-208.

Derrien, F., Kecskés, A., \& Thesmar, D. (2013). Investor Horizons and Corporate Policies. Journal of Financial and Quantitative Analysis, 48(06), 1755-1780.

Dyck, A., \& Zingales, L. (2004). Private Benefits of Control : An International Comparison. The Journal of Finance, 59(2), 537-600.

Ehikioya, B. I. (2009). Corporate governance structure and firm performance in developing economies: evidence from Nigeria. Corporate Governance, 9(3), 231-243.

Fama, E., \& Jensen, M. (1983). Separation of ownership and control. Journal of Law and Economics, 26(2), 301-325.

Farrell, K. a., \& Hersch, P. L. (2005). Additions to corporate boards: the effect of gender. Journal of Corporate Finance, 11(1-2), 85-106.

Firth, M., Fung, P. M. Y., \& Rui, O. M. (2007). How ownership and corporate governance influence chief executive pay in China's listed firms. Journal of Business Research, 60(7), 776-785.

Firth, M., Tam, M., \& Tang, M. (1999). The determinants of top management pay. Omega, 27(6), 617-635.

Florackis, C., Kostakis, A., \& Ozkan, A. (2009). Managerial ownership and performance. Journal of Business Research, 62(12), 13501357.

Graham, J. R., Li, S., \& Qiu, J. (2012). Managerial attributes and executive compensation. Review of Financial Studies, 25(1), 144-186.

Hermalin, B. E., \& Weisbach, M. S. (2003). Boards Of Directors As An Endogenously Determined Institution: A Survey Of The Economic Literature. FRBNY Economic Policy Review, (April), 7-26.

Hermalin, B., \& Weisbach, M. (1988). The determinants of board composition. Rand Journal of Economics, 19(4), 589-606.

Holderness, C. G. (2003). A Survey of Blockholders and Corporate Control. FRBNY Economic Policy Review, 9(1), 51-64.

Jensen, M., \& Meckling, W. (1976). Theory of the firm: Managerial behavior, agency costs and ownership structure. Journal of Financial Economics, 3, 305-360.

Johnson, S., Boone, P., Breach, A., \& Friedman, E. (2000). Corporate governance in the Asian financial crisis. Journal of Financial Economics, 58, 141-186.

Johnston, J., \& DiNardo, J. (1997). Econometric Methods (4th ed.). New York, NY: McGraw- Hill.

Kamardin, H., \& Haron, H. (2011). Internal corporate governance and board performance in monitoring roles: Evidence from Malaysia. Journal of Financial Reporting and Accounting, 9(2), 119-140.

Kato, T., Kim, W., \& Lee, J. H. (2007). Executive compensation, firm performance, and Chaebols in Korea: Evidence from new panel data. Pacific-Basin Finance Journal, 15(1), 36-55.

Khan, R., Dharwadkar, R., \& Brandes, P. (2005). Institutional ownership and CEO compensation: a longitudinal examination. Journal of Business Research, 58(8), 1078-1088.

Khan, W. a., \& Vieito, J. P. (2013). Ceo gender and firm performance. Journal of Economics and Business, 67, 55-66.

Kim, K. (2010). Blockholder monitoring and the efficiency of pay-performance benchmarking. Journal of Corporate Finance, 16(5), $748-$ 766. 
Koerniadi, H., \& Tourani-Rad, a. (2012). Does Board Independence Matter? Evidence from New Zealand. Australasian Accounting Business and Finance Journal, 6(2), 3-18.

Krivogorsky, V. (2006). Ownership, board structure, and performance in continental Europe. The International Journal of Accounting, $41(2), 176-197$.

La Porta, R., López de Silanes, F., Shleifer, A., \& Vishny, R. (1998). Law and finance. Journal of Political Economy, 106(6), $1113-1155$.

La Porta, R., Lopez-de-Silanes, F., \& Shleifer, A. (1999). Corporate ownership around the world. The Journal of Finance, 54(2), 471 517.

Lemmon, M. L., \& Lins, K. V. (2003). Ownership Structure , Corporate Governance, and Firm Value : Evidence from the East Asian Financial Crisis. The Journal of Finance, 58(4), 1445-1468.

Linck, J., Netter, J., \& Yang, T. (2008). The determinants of board structure. Journal of Financial Economics, 87(2), $308-328$.

Luo, Y., \& Jackson, D. O. (2012). Executive Compensation , Ownership Structure and Firm Performance in Chinese Financial Corporations. Global Business and Finance Review, 17(1), 56-74.

Mehran, H. (1995). Executive compensation structure, ownership, and firm performance. Journal of Financial Economics, 38, $163-184$.

Mitton, T. (2002). A cross-firm analysis of the impact of corporate governance on the East Asian financial crisis. Journal of Financial Economics, 64, 215-241.

Morck, R., Shleifer, A., \& Vishny, R. W. (1988). Management ownership and market valuation: An empirical analysis. Journal of Financial Economics, 20, 293-315.

Munisi, G., Hermes, N., \& Randøy, T. (2014). Corporate boards and ownership structure: Evidence from Sub-Saharan Africa. International Business Review, 23(4), 785-796.

Ozkan, N. (2007). Do corporate governance mechanisms influence CEO compensation? An empirical investigation of UK companies. Journal of Multinational Financial Management, 17(5), 349-364.

Rashid, A., De Zoysa, A., Lodh, S., \& Rudkin, K. (2010). Board Composition and Firm Performance: Evidence from Bangladesh. Australasian Accounting Business and Finance Journal, 4(1), 76-95.

Sanda, A., Mikailu, A., \& Garba, T. (2005). Corporate governance mechanisms and firm financial performance in Nigeria. African Economic Research Consortium, (March), 47.

Sanda, A. U., Garba, T., \& Mikailu, A. S. (2011). Board Independence and Firm Financial Performance : Evidence from Nigeria. African Economic Research Consortium, (January), 41.

Sarkar, J., \& Sarkar, S. (2009). Multiple board appointments and firm performance in emerging economies: Evidence from India. PacificBasin Finance Journal, 17(2), 271-293.

Shleifer, A., \& Vishny, R. (1997). A survey of corporate governance. The Journal of Finance, 52(2), 737-783.

Shleifer, A., \& Vishny, R. W. (1986). Large Shareholders and Corporate Control. Journal of Political Economy, 94(3), 461.

Singh, V., Terjesen, S., \& Vinnicombe, S. (2008). Newly appointed directors in the boardroom: European Management Journal, 26(1), $48-58$.

Wooldridge, J. (2002). Econometric Analysis of Cross Section and Panel Data. Cambridge, Massachusetts: The MIT Press.

Yermack, D. (1996). Higher market valuation of companies with a small board of directors. Journal of Financial Economics, 40(2), 185211. 